\title{
Investigation, study and practice of optoelectronic MOOCs
}

Jianhua Shi, Wei Liu, Bing Lei, Tianfu Yao, Sihua Fu

Jianhua Shi, Wei Liu, Bing Lei, Tianfu Yao, Sihua Fu, "Investigation, study and practice of optoelectronic MOOCs," Proc. SPIE 10452, 14th Conference on Education and Training in Optics and Photonics: ETOP 2017, 1045243 (16 August 2017); doi: 10.1117/12.2266458

SDIE Event: 14th Conference on Education and Training in Optics and Photonics, ETOP 2017, 2017, Hangzhou, China 


\title{
Investigation, study and practice of opto-electronic MOOCs \\ Jianhua Shi*, Wei Liu, Bing Lei, Tianfu Yao and Sihua Fu \\ College of Opto-electronic Science and Engineering, National University of Defense Technology, Changsha 410073, China
}

\begin{abstract}
MOOC(Massive Open Online Course) is a new teaching model that has been springing up since 2012. The typical characters are short teaching video, massive learners, flexible place and time to study, etc. Although MOOC is very popular now, opto-electronic MOOCs are not much enough to meet the need of online learners. In this paper, the phylogeny, the current situation and the characters of MOOC were described, the most famous MOOCs' websites, such as Udacity, Coursera, edX, Chinese College MOOC, xuetangx, were introduced, the opto-electronic MOOCs come from these famous MOOCs' website were investigated extensively and studied deeply, the "Application of Opto-electronic Technology MOOC" which was established by our group is introduced, and some conclusions are obtained. These conclusions can give some suggestions to the online learners who are interested in opto-electronic and the teachers who are teaching the opto-electronic curriculums. The preparation of "Opto-electronic Technology MOOC" is described in short.
\end{abstract}

Keywords: MOOC, teaching model, opto-electronic technology, teaching video

\section{INTRODUCTION}

MOOC (Massive Open Online Course) is a new teaching model that has been springing up since 2012. Different from the traditional teaching model, MOOCs are online courses that designed for large numbers of autonomous learners, and everyone can study the courses anywhere and at any time.

The typical characters of MOOCs are high quality contents, short teaching video, new evaluation model, massive learners and strong radiation. It has attracted many scholars in education, science, commerce, etc. Many famous university, such as Standford、Harvard、MIT, have put much attention to MOOCs and many MOOCs platform have been built. Currently, the most famous international MOOCs platform includes Udacity, Coursera, edX, Futurelearn, Open2study.

In China, many universities such as Tsinghua University, Peking University, the University of Hong Kong, the National University of Defense Technology, etc., also put much attention on MOOCs. Anyone can learn the MOOCs come from these universities on edX, Coursera, xuetangx, Chinese College MOOC, etc.

In order to help the students to study the opto-electronic courses effectively and construct a systemic opto-electronic knowledge, we investigate the opto-electronic courses on the most famous MOOC platform. Based on mastering the existing courses we built two opto-electronic MOOC courses: Application of Opto-electronic Technology and Optoelectronic Technology.

\section{INVESTIGATION OF OPTO-ELECTRONIC MOOCS}

\subsection{Introduction of the most famous MOOC platforms}

Coursera, edX and Udacity are the most famous international MOOC platforms. In April 2012, Coursera was built by Daphne Koller and Andrew Ng, two professors of Stanford University. Now there are 2000+ courses from schools like Stanford University, University of Michigan, Princeton University, University of Pennsylvania, etc. All courses on this platform are free. The number of the students that have registered Coursera platform is bigger than 680000. Edx also offers free online courses. It was built in April 2012 by Massachusetts Institute of Technology and Harvord University. Udacity is a profit online education organization. It was built in 2011 by Sebastian Thrun. Everyone can learn the courses on this platform free of charge, but he must pay for the certificate if he needs it.

*gexin7651@sina.com; phone 86-013974942184

14th Conference on Education and Training in Optics and Photonics: ETOP 2017, edited by Xu Liu,

Xi-Cheng Zhang, Proc. of SPIE Vol. 10452, 1045243 • ( 2017 ICO, IEEE, OSA, SPIE

CCC code: $0277-786 X / 17 / \$ 18 \cdot$ doi: $10.1117 / 12.2266458$ 
Chinese College MOOC and xuetangx are the most famous MOOC platform in China. Chinese College MOOC is built by the ministry of education and the ministry of finance. Its courses come from the most famous university in China, such as Zhejiang University, Xi' an Jiaotong University, the National University of Defense Technology. Xuetangx is built by Tsinghua University in October 2013. The courses on this platform come from Tsinghua University, Peking University, Fudan University, Stanford University, Massachusetts Institute of Technology, etc. Figure 1 gives the screenshots of the five websites ${ }^{[1]-[5]}$.
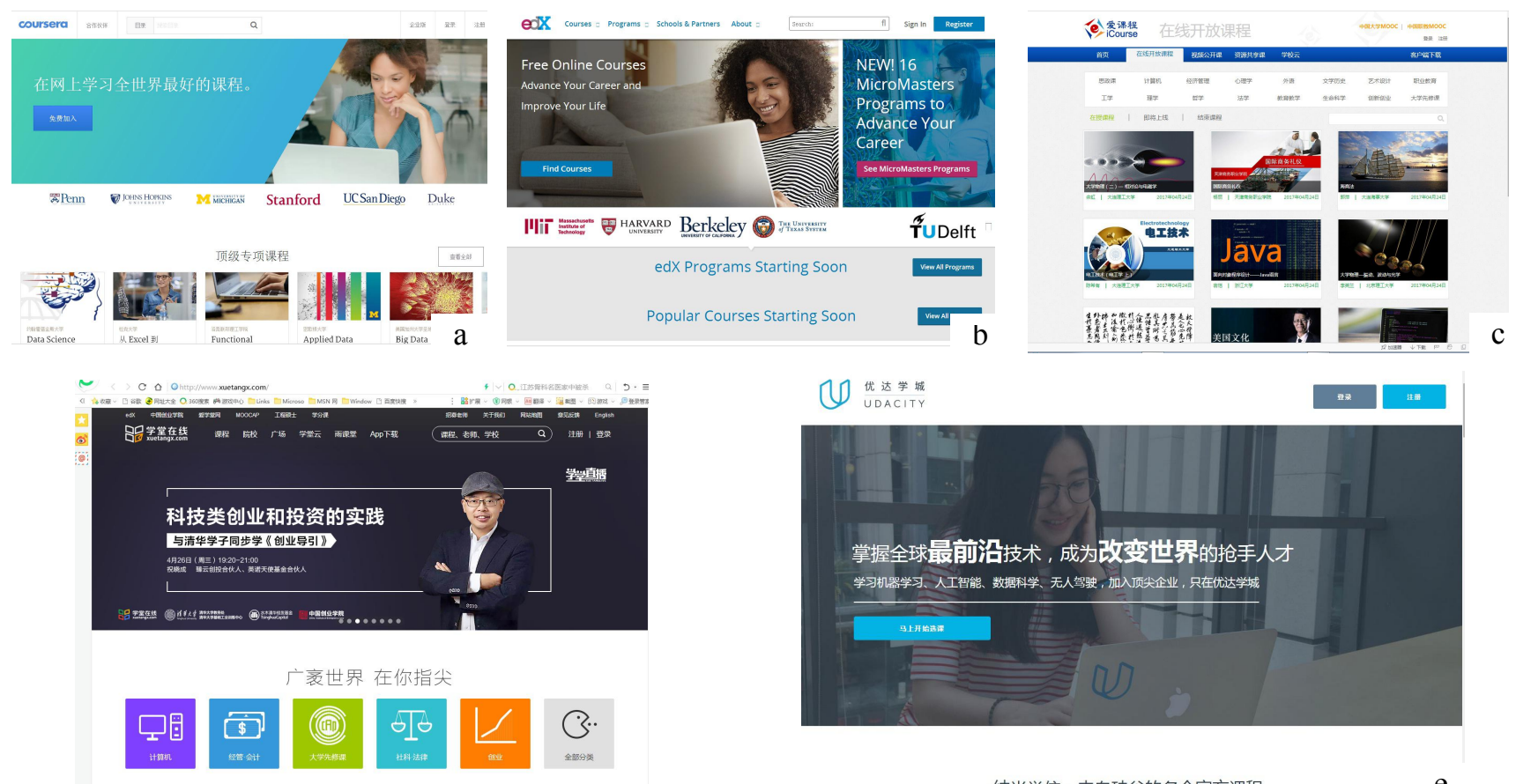

Figure 1. Screenshots of the most famous MOOC platform: (a) Coursera . (b) edX. (c) Chinese College MOOC . (d) xuetangx. (f) Udacity

\subsection{Investigation of Opto-electronic MOOCs on the five MOOC platforms}

We used "light", "laser", "photon", "optic", and "optoelectronic" to search the five platforms. The results show that there is no optics or opto-electronic course on Udacity platform. Table 1 4 give the title, the main content, the instructor, the university and the duration of each opto-electronic course on the other four platforms (the data is up to 4/24/2017).

From table 1 we can see that there are three optics courses on the coursera platform: Nonlinear optics, Quantum Optics 1:Single Photons, Basic Optics I. Two of them come from French and one comes from China. All of the three courses are theoretical.

Table 1. Optics or opto-electroic courses on the coursera platform.

\begin{tabular}{|c|l|c|l|l|}
\hline Title & \multicolumn{1}{|c|}{ Main Content } & Instructor & \multicolumn{1}{c|}{ University } & Duration \\
\hline Nonlinear optics & Introduction of nonlinear optics & Manuel Joffre etc & Ecole Polytechnique & \\
\hline $\begin{array}{l}\text { Quantum Optics } \\
\text { 1:Single Photons }\end{array}$ & Quantization of light & Alain Aspect & Ecole Polytechnique & $\begin{array}{l}\text { 7weeks of } \\
\text { study, 4-5 } \\
\text { hours/week }\end{array}$ \\
\hline Basic Optics I & $\begin{array}{l}\text { Optical phenomena in our daily } \\
\text { life }\end{array}$ & Chu Shiwei & $\begin{array}{l}\text { National Taiwan } \\
\text { Universit }\end{array}$ & 14 hours \\
\hline
\end{tabular}


Table 2 shows that there are four optics courses on the edX platform: Atomic and Optical Physics: Light Forces and Laser Cooling, Waves \& Optics, Optical Materials and Devices, Silicon Photonics Design, Fabrication and Data Analysis. Two of them come from Massachusetts Institute of Technology, America, one comes from Rice university, America, and one comes from the University of British Columbia, UK. Except the "Waves \& Optics", the other three courses are engineering.

Table 2. Opto-electroic courses on the edX platform.

\begin{tabular}{|c|l|l|l|l|}
\hline Title & \multicolumn{1}{|c|}{ Main Content } & \multicolumn{1}{|c|}{ Instructor } & \multicolumn{1}{|c|}{ University } & \multicolumn{1}{|c|}{ Duration } \\
\hline $\begin{array}{c}\text { Atomic and Optical } \\
\text { Physics: Light Forces } \\
\text { and Laser Cooling }\end{array}$ & $\begin{array}{l}\text { Light forces, laser cooling and how to create } \\
\text { optical atom traps }\end{array}$ & $\begin{array}{l}\text { Wolfgang } \\
\text { Ketterle, } \\
\text { David E. } \\
\text { Pritchard, } \\
\text { Isaac Chuang }\end{array}$ & $\begin{array}{l}\text { Massachusetts } \\
\text { Institute of } \\
\text { Technology }\end{array}$ & $\begin{array}{l}4 \text { weeks, } \\
10 \sim 12 \\
\text { hours per } \\
\text { week }\end{array}$ \\
\hline Waves \& Optics & $\begin{array}{l}\text { The physics of waves on strings, } \\
\text { electromagnetic waves, geometrical optics, } \\
\text { interference, diffraction, and image formation. }\end{array}$ & $\begin{array}{l}\text { Jason Hafner, } \\
\text { Lam Yu }\end{array}$ & $\begin{array}{l}\text { Rice } \\
\text { university }\end{array}$ & $\begin{array}{l}11 \text { weeks, } \\
\text { hours } \\
\text { per week }\end{array}$ \\
\hline $\begin{array}{c}\text { Optical Materials and } \\
\text { Devices }\end{array}$ & $\begin{array}{l}\text { The optical properties of materials, including } \\
\text { how LEDs, lasers, and solar cell devices are } \\
\text { designed. }\end{array}$ & Caroline Ross & $\begin{array}{l}\text { Massachusetts } \\
\text { Institute of } \\
\text { Technology }\end{array}$ & $\begin{array}{l}6 \text { weeks, } \\
8 \sim 12 \\
\text { hours per } \\
\text { week }\end{array}$ \\
\hline $\begin{array}{c}\text { Silicon Photonics } \\
\text { Design, Fabrication } \\
\text { and Data Analysis }\end{array}$ & $\begin{array}{l}\text { Design silicon photonics chip, include } \\
\text { photonics fabrication, experimentation, and } \\
\text { data analysis. }\end{array}$ & $\begin{array}{l}\text { The } \\
\text { University of } \\
\text { British } \\
\text { Columbia }\end{array}$ & $\begin{array}{l}7 \\
3 \sim 25 \\
\text { hours per } \\
\text { week }\end{array}$ \\
\hline
\end{tabular}

Table 3 shows that there are four optics courses on the xuetangx platform, Waves \& Optics and Optical Materials and Devices are also appearing on the edX platform. The other two courses, Fundamentals of Optical Engineering and Design of Photoelectric Instrument, come from the Tsinghua University. The main contents show that these two courses are engineering.

Table 3. Opto-electroic courses on the xuetangx platform.

\begin{tabular}{|c|l|l|l|l|}
\hline Title & \multicolumn{1}{|c|}{ Main Content } & \multicolumn{1}{|c|}{ Instructor } & University & \multicolumn{1}{c|}{ Duration } \\
\hline $\begin{array}{c}\text { Fundamentals of } \\
\text { Optical Engineering } \\
\text { applications of optical engineering }\end{array}$ & $\begin{array}{l}\text { The basic conceptions and practical } \\
\text { Tan Qiaofeng, } \\
\text { etc. }\end{array}$ & $\begin{array}{l}\text { Tsinghua } \\
\text { University }\end{array}$ & $\begin{array}{l}6 \text { hours per } \\
\text { week }\end{array}$ \\
\hline $\begin{array}{c}\text { Design of Photoelectric } \\
\text { Instrument }\end{array}$ & The design of photoelectric instrument & $\begin{array}{l}\text { Wu Guanhao, } \\
\text { Zeng Lijiang, } \\
\text { etc }\end{array}$ & $\begin{array}{l}\text { Tsinghua University } \\
\text { act on one's } \\
\text { own }\end{array}$ \\
\hline $\begin{array}{c}\text { Waves \& Optics } \\
\text { electromagnetic waves, geometrical optics, } \\
\text { interference, diffraction, and image formation. }\end{array}$ & $\begin{array}{l}\text { Jason Hafner, Yu } \\
\text { Lam Yuce } \\
\text { university }\end{array}$ & $\begin{array}{l}11 \\
10 \text { hours per } \\
\text { week }\end{array}$ \\
\hline $\begin{array}{c}\text { Optical Materials and } \\
\text { Devices }\end{array}$ & $\begin{array}{l}\text { The optical properties of materials, including } \\
\text { how LEDs, lasers, and solar cell devices are } \\
\text { designed. }\end{array}$ & $\begin{array}{l}\text { Caroline Ross } \\
\text { Institute } \\
\text { Technology } \\
\text { of }\end{array}$ & $\begin{array}{l}6 \\
8 \sim 12 \\
\text { per week } \\
\text { hours }\end{array}$ \\
\hline
\end{tabular}

Table 4 shows that there are five optics or optoelectronic courses on the Chinese College MOOC platform: Physical Optics, Applied Optics, Wave Optics, Optoelectronics (I), Optoelectronics (II). All courses on this platform are built by Chinese universities. Two come from Xi'an Jiaotong University, one comes from Harbin Institute of Technology, one 
comes from Beijing Institute of technology, and one comes from East China Normal University. The main contents of the five courses show that they are theoretical courses.

Table 4. Opto-electroic courses on the Chinese College MOOC platform.

\begin{tabular}{|c|c|c|c|c|}
\hline Title & Main Content & Teacher & University & Duration \\
\hline Physical Optics & $\begin{array}{l}\text { Propagation of light, interaction of } \\
\text { light and material }\end{array}$ & Hass U Ligi & $\begin{array}{l}\text { Harbin } \\
\text { Institute of } \\
\text { Technology }\end{array}$ & $\begin{array}{l}11 \text { weeks, } 5 \\
\text { hours per week }\end{array}$ \\
\hline Applied Optics & $\begin{array}{l}\text { Basic theory of geometrical optics, } \\
\text { radiometry and photometry, estimation } \\
\text { of imaging quality. }\end{array}$ & $\begin{array}{l}\text { Huang Yifan, } \\
\text { LiLin ect. }\end{array}$ & $\begin{array}{l}\text { Beijing } \\
\text { Institute of } \\
\text { technology }\end{array}$ & $\begin{array}{l}11 \text { weeks, } 3 \sim 6 \\
\text { hours per week }\end{array}$ \\
\hline Wave Optics & Wave theory of light. & $\begin{array}{l}\text { Guan Shuguang, } \\
\text { Liu Jinming, } \\
\text { etc }\end{array}$ & $\begin{array}{l}\text { East China } \\
\text { Normal } \\
\text { University }\end{array}$ & $\begin{array}{l}12 \text { weeks, } 4 \sim 6 \\
\text { hours per week }\end{array}$ \\
\hline Optoelectronics (I) & $\begin{array}{l}\text { Introduction of optoelectronic, } \\
\text { propagation of light, laser, fiber and } \\
\text { optic waveguide. }\end{array}$ & Zhu Jingping & $\begin{array}{l}\text { Xi'an Jiaotong } \\
\text { University }\end{array}$ & $\begin{array}{l}13 \text { weeks, } 1 \sim 3 \\
\text { hours per week }\end{array}$ \\
\hline Optoelectronics (I I) & $\begin{array}{l}\text { Modulation of light, detection of light, } \\
\text { display of light, passive device, optical } \\
\text { storage }\end{array}$ & Zhu Jingping & $\begin{array}{l}\text { Xi'an Jiaotong } \\
\text { University }\end{array}$ & $\begin{array}{l}13 \text { weeks, } 1 \sim 2 \\
\text { hours per week }\end{array}$ \\
\hline
\end{tabular}

\subsection{Summarization}

From the investigation above we find there are only fourteen optics/opto-electronic courses on the five famous MOOC platforms. These courses can't meet the need of the learner who wants to construct a systemic opto-electronic knowledge. Compared with the American MOOC platform, there are more optical courses or opto-electronic courses on Chinese MOOC platform. The average duration of Chinese MOOCs is longer than that of other countries. The optoelectronic courses are less than optics courses. Based on this conclusion, we decided to build some opto-electronic MOOCs. In our school, Opto-electronic Technology is a important and required course for the student whose major is opto-electronic engineer, optical information or optical engineering. It is also the base of many courses, such as fiber optics, optoelectronic system, opto-electronic experiments, etc. It is so important that we have paid much attention on it, and now it has been the excellent course of Hunan province. The Application of Opto-electronic Technology is another important excellent course in our school. Based on above, we decided to build two opto-electronic MOOC: Opto-electronic Technology and Application of Opto-electronic Technology.

\section{STUDY AND PRACTICE ON THE APPLICATION OF OPTO-ELECTRONIC TECHNOLOGY MOOC $^{[6]}$}

\subsection{The contents of the Application of Opto-electronic Technology MOOC}

Opto-electronic technology combines the traditional optics and electronics. In the military, it makes the weapon detect or attack the object more accurately. The main content of the Application of Opto-electronic Technology MOOC includes the introduction of opto-electronic technology, optoelectronic scouting technology, photoelectric display technology, integrated electro-optical reconnaissance system, photoelectric fire control technology, photoelectric guidance technology, optoelectronic countermeasure technology, the outlook of optoelectronic technology.

For each class of optoelectronic equipment, the basic principle, the structure, the key components and the important characters are described first. Then the different types of the equipments are compared and typical equipments are analyzed deeply. At last, the matters that need attention are introduced.

\subsection{The design and recording of the teaching videos}

Teaching video is the main way of information deliver. If a teaching video is shorter than 2 minutes, it is hard for the students to understand the knowledge deeply. If a teaching video is longer than 20 minutes, the student may distract from 
the video. Based on above, the duration of our teaching video is about 15 minutes. Around the key knowledge points, questions are bought out between two teaching videos.

To make the contents easy to understand, many pictures, animations, experiment videos, virtual experiments are inserted. The three point screen is used so that the students can see the teacher's body movement which may help the student to understand the knowledge. The important sentences are marked and the importance equations are derived by the screen writing pen.

\subsection{The application of the course}

The course was open in April, 2014. There are four sections need to managed. (1) The information of the course, such as the title, duration, type and subject of the course, university that provide the class, introduction of the video, the score, etc. (2) The statistics of the course, such as the number of the students, the progress of learning, etc. (3) The management of the course's contents, such as upload the teaching video, set some basic exercises to check up if the students have master the knowledge, announcements of the course, the discussion and the reference.(4) Discussion section is set for the students to ask questions and the teacher answer the questions.

\subsection{Summarization and improvement}

By analyzing the questions that the students bring forward, the progress of learning, the students' scores etc, the following conclusions can be obtained: (1) Many students are interested at the course; (2) Only a few of students can keep up with the teacher, most students lag behind seriously. (3) About 20 percent students are very actively, they ask many questions after each teaching video. (4) The student's background knowledge varies widely.

Next, we will optimize the structure of the course, strengthen the connection between the contents, design more questions and examinations, take some measures to encourage the students answer the questions.

\section{PREPARATION OF OPTO-ELECTRONIC TECHNOLOGY MOOC}

The second MOOC that we decided to build is Opto-electronic Technology. Its contents include ${ }^{[7][8]}$ : (1) Radiation source; (2) Introduction of opto-electronic detector; (3) Photoconductive detector; (4) Photovoltaic detector; (5) Photoelectron emission detector; (6) Thermal detector; (7) Photoelectric imaging device; (8) Optical signal modulation; (9) Direct detector and coherent detector; (10) Photoelectric detection circuit; (11) Typical photoelectric systems.

Now we have explored all the resources, include twelve flash animations, eight virtual experiments, four demonstration experiments, near 1000 pages notes, 1000+ exercises and all the teaching video. Figure 2 shows the screenshot of the teaching video and figure 3 shows the teaching note, animation, virtual experiments and demonstration experiments ${ }^{[9]}$.

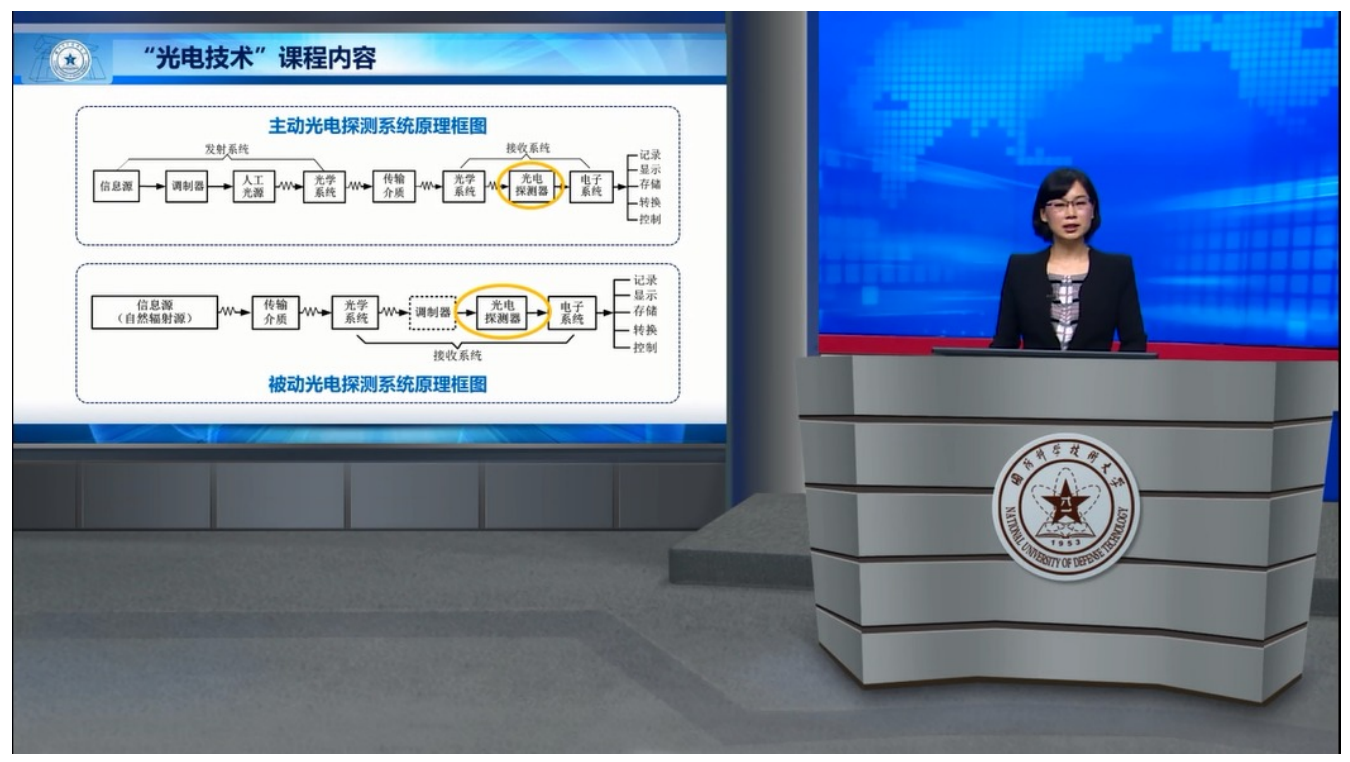

Figure 2. Screenshot of the teaching video 

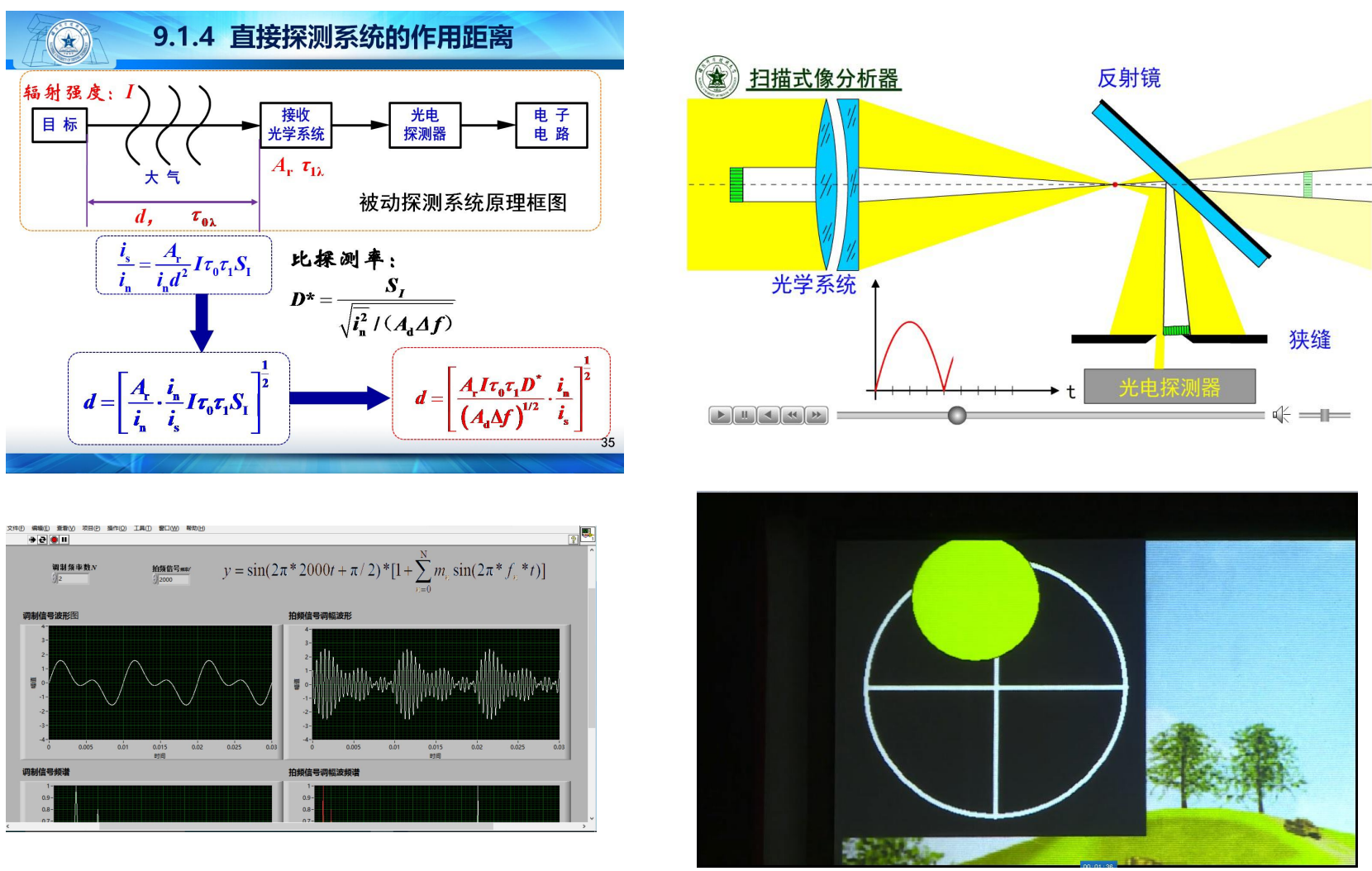

Figure 3. Screenshot of teaching note, animation, virtual experiment and demonstration experiments

\section{CONCLUSIONS}

With the development of information technology and computer technology, MOOC has been a popular teaching model and it provides a new method to learn by oneself. Although there are many courses on the MOOC platforms, the optics and optoelectronic courses are not much enough to meet the need of the students whose major is optical engineer.

MOOC is a new teaching model and there are still a lot of things need to do and study. Our experience of MOOCs' building and teaching show that a MOOC need a lot of work and it is a big challenge for the teachers. The students should change their study habits to fit this online teaching model and the teacher should grow their field of knowledge.

\section{REFERENCES}

[1] http://www.coursera.org/

[2] http://www.udacity.com/

[3] http://www.edx.org/

[4] http://www.xuetangx.com/

[5] http://www.icourses.cn/imooc/

[6] Shi Jianhua, Duan Chengfang, Hu Haojun etc. "Practice and discussion on Military Opto-Electronic Technology and Application MOOC course", Computer Engineering \& Science, 36(s2):246-249(2014)

[7] Jiang Wenjie and Shi Jianhua, Xie Wenke etc. [Optoelectric technology], Science Press, Beijing, vi-xii(2014)

[8] Shi Jianhua, Ma Haotong, Jiang Wenjie etc. "Research on 'theory-practice-innovation' trinity Network Course", Journal of Higher Education Research, 37(4):84-88(2014)

[9] http://jpkc2010.nudt.edu.cn/gdjs/ 